Lunkka, N., Pietiläinen, V., \& Suhonen, M. (2019). A Discursive Sensemaking

Perspective on Project-Based Work in Public Healthcare. Project Management Journal. https://doi.org/10.1177/8756972819847062

\title{
A DISCURSIVE SENSEMAKING PERSPECTIVE ON PROJECT-BASED WORK IN PUBLIC
}

HEALTHCARE

\begin{abstract}
This study investigated project participants' sensemaking of lived work experiences during organizational change within Finnish public healthcare. The study introduced a discursive sensemaking perspective to investigate lived experiences, i.e. reflexive practitioners' situational thinking. Drawing upon 17 interviews, the research identified diverse repertoires through which the lived experiences were authored meaningful: repertoires of 1) transformation, 2) realism, 3) politics, 4) individuality, 5) reflexivity and 6) senselessness. The results showed that project-based work in public healthcare differs from project participants' expectations as projects were perceived to increase, rather than decrease, bureaucracy and include unsustainable working conditions that have to be endured.
\end{abstract}

Keywords: lived experience, project-based work, sensemaking, discourse, healthcare

\section{INTRODUCTION}

Project-based work has become an increasingly utilized medium to make necessary organizational changes within public healthcare (e.g. Kitzmiller, Anderson \& McDaniel, 2010; Aubry, Richer \& Lavoie-Tremblay 2014; Winch, Meunier, Head \& Russ, 2011). Project-based work refers to work that is organized into distinct, complex tasks limited in both time and scope (Lindgren, Packendorff \& Sergi, 2014). However, change projects often largely focus on change control and, therefore, the complex characteristics associated with the changes necessary to deliver value are often ignored (Crawford, Aitken \& Hassner-Nahmias, 2014; Aubry et al., 2014; Midler, 1995; Lundin, Arvidson, Brady, Ekstedt, Midler \& Sydow, 2015). Public healthcare also comprises professional, bureaucratic and hierarchic organizations (e.g. Bate, 2000), a dynamic that presents challenges for public healthcare change projects that utilize project-based work (Lunkka \& Suhonen, 2015; see also Suhonen \& Paasivaara, 2015). Therefore, healthcare change projects should be studied in a way that accounts for their emergent nature and unique context (see Aubry \& Lavoie-Tremblay, 2018; Aubry et al., 2014; Winch et al., 2011).

It has been pointed out that traditional and universal project studies - those that aim to provide normative and universal knowledge on how to improve project management - cannot consider the contextual and situational dimensions of projects (e.g., Lalonde, Bourgault \& Findeli, 2010; Cicmil \& Hodgson, 2006). The main argument for this proposition is that traditional project studies, although sound, use "deductive logic as a paradigm to account for the practical application of a universal theoretical proposal to a project situated within a particular socio-historical context" (Lalonde et al., 2010, p. 27). As a result, normative project studies have been criticized for their weak relevance to practice. To enhance the understanding of healthcare change projects in a way that both considers the context and has practical relevance, we have 
focused on what actually happens in the arrangements labeled 'healthcare change projects' (Cicmil, Williams, Thomas \& Hodgson, 2006). By concentrating on the reality of the projects as perceived by project participants, we provide insight into healthcare change projects 'from the inside'. According to Geraldi's \& Söderslund's (2018, p. 61) typology, the present study can be positioned as type three project research, which focuses on the actuality of projects but also invites "reflection and transformation of the taken-for-granted assumptions of the status quo". This understanding can be used to improve current project management practices in healthcare change projects (c.f. Lalonde et al., 2010).

When focusing on the actuality of healthcare change projects, it is necessary to situate these projects within existing and emerging social relations (Sampaio, Marinho \& Moura, 2014). Therefore, it is important to emphasize that healthcare change projects are social constructs, whereby reality is contingent upon project members creating meaning (see Bettis \& Gregson, 2008). However, it is "not just about the human construction of meaning as if it were independent of phenomena in the world," but it "is human interaction with the world and how humans then make sense of that interaction" (Bettis \& Gregson 2001, p. 10, italics added). A project actuality approach provides a way to focus on the creation of meaning based on the reciprocal interaction between the 'human and the world,' because this approach acknowledges that healthcare change projects do not exist as ready-made, neutral, and given but are "constituted by the actions of interdependent actors" through the process of "conversational relating in the medium of symbols which act as representations of shared meaning and directions for action" (Cicmil et al., 2006, 677). One way to explore how this meaning is created is to focus on project participants' lived experiences (Cicmil et al., 2006), i.e. focus on how practitioners think in action, which transcends the project itself (Sampaio et al., 2014).

Language is the central medium for transmitting meanings, and provides "a methodological orientation for a phenomenology of social life that is concerned with the relation between language use and the objects of experience" (Goulding 2005, 302). In this article, we adopt a discursive sensemaking perspective to elaborate the relationship between language use and objects of lived experiences. This discursive sensemaking perspective uses Weick's (1995) notion of sensemaking as a starting point. Sensemaking is a lens through which it is possible to understand the lived experience of organizing (Maitlis, Vogus \& Lawrence, 2013) as a constructive practice (Sandberg \& Tsoukas, 2015). Therefore, instead of focusing on actual actions or behaviors in the context of an ongoing healthcare change project, we access the project actuality through project participants' retrospective sensemaking of their lived project work experiences. We focus on how project participants use practical reasoning in their retrospective sensemaking accounts and concentrate "on praxis, on context-dependent judgment, on situational ethics and on reflexivity" in these accounts (Cicmil et al., 676-677). 
During the process of sensemaking, people retrospectively make sense of their experiences to seek plausibility for ambiguous, equivocal, or confusing issues or events (Brown, Colville \& Pye 2015; Maitlis, 2005; Weick, 1995). Sensemaking is an issue of language, talk, and communication because "situations, organizations and environments are talked into existence" (Weick, Sutcliffe \& Obstfeld, 2005, p. 409). As such, sensemaking concerns making something meaningful and sensible (Sandberg \& Tsoukas, 2015), a process which "involves turning circumstances into a situation that is comprehended explicitly in words" (Weick et al., 2005, 409). Consequently, scholars have become increasingly interested in exploring how sense is made through discourse (see Brown et al., 2015). Brown et al. (2015) suggest that individual-level sensemaking may not only be embedded within organizations but may also have consequences for them. By employing a discursive sensemaking perspective, we introduce a way to investigate this relationship. Drawing on previous work that has integrated sensemaking within the discursive environment (Helms Mills, Thurlow \& Mills, 2010), this article aims to clarify how individual project participants' retrospective sensemaking of lived project work experiences produces and reproduces the understanding of the healthcare change project phenomena through discourses. However, it should be noted that the approach used in this article can be leveraged to research problems associated with project work within sectors or industries other than healthcare.

In sum, by focusing on project participants' lived project work experiences, this article contributes to project actuality research, particularly in healthcare context, and elaborates how project actors' retrospective sensemaking is influenced, and influences, the project environment in which the actors are embedded. The article further describes how different lived project work experiences are made sense of within the environment in which they occur and how the enacted meanings (re)produce this same environment. Thus, the perspective adopted in this article views the world as being in a state of continual flux (see van de Ven \& Poole 2005) that is both stabilized and enacted through the process of sensemaking (Weick \& Quinn 1999). In particular, we investigate how patterns of discourse influence the retrospective sensemaking accounts of various project participants' lived project work experiences. By treating these retrospective sensemaking accounts as performative, we highlight the variety of these enacted meanings and use the polyphony of project participants' lived work experiences to analyze what kind of reality the discursive sensemaking accounts produce in the context of a healthcare change project. The results show that sensemaking accounts of lived experiences from healthcare change projects legitimize project-based work as worth pursuing, take for granted unsustainable working conditions, as well as the boundaries between different parties, and only marginally aim for diversity and receptiveness. In the following sections, after demonstrating the value of the chosen discursive sensemaking perspective through a 
review of contemporary project management literature focused on public organizations and healthcare, we explicate this perspective and its included terms in more detail.

\section{THEORETICAL UNDERPINNINGS}

\section{Organizational Change Projects within Public Healthcare}

It is both relevant and necessary to explore the lived experiences of project-based work within public healthcare, a sector that comprises distinct and unique organizations. These organizations are politically and administratively regulated (Löfgren \& Poulsen, 2013), with different hierarchical professions, each with their own social and cultural norms (San Martin-Rodriguez, Beaulieu, Dámour \& Ferrada-Videla, 2005; Bate, 2000), that are presumed to collaborate for the best of the patients (Bender, Connelly \& Brown, 2013; Jordan, Lanham, Crabtree, Nutting, Miller, Stange \& McDaniel, 2009). Public healthcare projects typically involve, and are managed by, these various healthcare professionals (Pohjola, 2016). Moreover, public healthcare organizations tend to organize specialties into distinct silos, another characteristic which makes co-operation challenging (cf. Bender et al., 2013; Jordan et al., 2009; San Martin-Rodriguez et al., 2005).

Based on rational interpretation, projects in public organizations are expected to provide more efficient and flexible alternatives to the traditional bureaucratic forms of organizing (cf. Sjöblom, Löfgren \& Godenhjelm, 2013). They are regarded as symbols for streamlining processes, decisiveness and entrepreneurship (Jensen, Johansson \& Löfström, 2013; Sjöblom et al., 2013). In addition, projects are considered a means to facilitate multidisciplinary collaboration that supports learning and participation (see Lunkka \& Suhonen, 2015). There have also been suggestions that projects will increase innovativeness (Sbareca \& Martins, 2003), as well as that significant added value can be gained through these temporal 'knowledge organizations' (Lindner \& Wald, 2011). However, unless researchers explore the actuality of project-based work in healthcare, we cannot understand how these dimensions of project-based work are socially constituted (see Hodgson \& Cicmil, 2006).

Nevertheless, there has only been a limited number of project studies that have explicitly investigated lived experiences during recent years (van der Hoorn, 2015). Many of these studies have focused on the lived experiences of project managers (e.g. van der Hoorn, 2015; Hodgson, Paton \& Cicmil, 2011). There is still a need for studies that focus particularly on the lived experiences of project workers (see Cicmil et al., 2006), and this article contributes to this research gap in a public healthcare field. 
Earlier studies of lived experiences of project-based work that have concentrated on project workers have indicated that the performative and traditional discourse of project management has institutionalized a certain view of project management and project-based work (Lindgren et al., 2014). Project-based work includes the promise of exciting adventures that are experienced under conditions of rational control, but, at the same time, also involves suppressed and negative dimensions that describe the project as something inevitable that must be endured (Lindgren \& Packendorff, 2006; Hodgson \& Cicmil, 2007).

Cicmil, Lindgren \& Packendorff (2016) examined how discourses related to projects and project management influence the organization of contemporary work and what implications they have for project workers. They argued that the discursive 'projectification' of work-life exposes people to unsustainable working conditions regarding overload and deadline stress. This 'projectification' also contributes to a declining perception of progress, hope, and personal worthiness among project workers. Thus, the authors feel as though we must explicitly recognize the finiteness of temporal, human and social resources in project-based work, as well as the ensuing unsustainability of projectified work (Cicmil et al., 2016). However, studies that explore lived experiences of project-based work in the context of public healthcare have remained rare or even negligible. We know little about how project and project management discourses affect project workers within public healthcare. In order to improve the practices related to project-based work, it is important to reflect the lived experiences related to the matter. With this article, we hope to provide knowledge for this aspect.

\section{Approaching Lived Experiences from a Discursive Sensemaking Perspective}

In this article, the term lived experience refers to reflexive practitioners' situational thinking (Cicmil et al., 2006). Hence, it does not refer to project participants' experiences in a modelled sense, but rather how project participants live through and respond to project-related experiences (see Cicmil et al., 2006). The prefix 'lived' draws from phenomenologists such as Schutz and his analysis of lived experiences (Weick, 1995; see also Sandberg \& Tsoukas, 2015) which states that in order to capture the reality, project participants can only know what they are doing after they have done it (Weick, 1995). In other words, when making sense of their project work experiences, project participants must turn their attention to their lived experience and, as a result, they no longer simply live "with the flow" (Schutz, 1967; Weick, 1995). Through retrospective sensemaking accounts, project participants are able to describe their own world, or 'being-in-the-world' as Heidegger (1962) states it. As a result of this sensemaking, they also become aware of their participation in this world (Lindseth \& Norberg, 2004) meaning that lived experiences do not occur separately from the wider social world (cf. 
Billig, 2009). Meanings of lived experiences are also created "by virtue of the words which are available, and the resulting meanings contribute to producing the experience rather than being merely a description of the experience or an 'after-theevent’ occurrence” (Jørgensen \& Phillips, 2002, p. 103). As such, we follow the notion that language has a constitutive role in organizations.

We have developed a conceptual framework of discursive sensemaking to capture project participants' lived experiences in line with the theories described above. Drawing upon various linguistic theories, the sensemaking perspective describes how people enact and appropriate their realities (Brown et al., 2015; Sandberg \& Tsoukas, 2015; Maitlis \& Christianson, 2014) through communicative processes (Weick, 1995). We use discursive sensemaking to investigate how project participants' lived experiences are made sense of through discourse. Because the difference between language and discourse is not always clear, we first elaborate this matter in more detail.

Potter \& Wetherell (1987) consider discourse - or interpretive repertoire as they often call it - as text and talk in social practice. In their view, language is a medium for interaction, and the focus is on how people use their language in a particular social setting (Potter 1996). Foucault (1976; 1980), whose work epitomizes the discursive macro perspective, states that discourses can be seen as a set of statements that constitute both subjects and objects. Therefore, language arranges and naturalizes the social world "in a specific way and thus informs social practice" (Alvesson \& Kärreman 2000, 1127). The two perspectives - Potter \& Wetherell's as well as Foucault's - constitute distinctive traditions in discursive studies that have different views on the term meaning, defined here as "a relatively stable way of relating to and making sense of something, a meaning being interrelated to an attitude, value, belief or idea" (Alvesson \& Kärreman, 1128). For Foucault $(1976 ; 1980)$, discourse incorporates and precedes subjectivity and cultural meaning whereas the opinion of Potter and Wetherell (1987) is that discourse refers to the level of talk and, in this way, is only loosely coupled to the level of meaning, i.e. meaning is a transient concept (Alvesson \& Kärreman, 2000).

In the discursive sensemaking perspective, discourse refers to "patterns of meaning which organize the various symbolic systems human beings inhabit, and which are necessary for us to make sense to each other" (Parker, 1999, p. 3). In other words, discourses are seen as relatively stable meaning systems and the process of sensemaking is considered to be embedded in discourses, which influence and restrict the possibilities of thought (c.f. Helms Mills et al., 2010). However, we have not followed Foucault's perspective, such as Helms Mills et al. (2010) in their critical sensemaking approach, because then the research would focus on investigating merely how project practitioners' experiences embody a particular 
discourse. Instead, the discursive sensemaking perspective focuses on the polyphony of language use, through which meaning is authored to lived experiences. We consider discourses to be constructed in the sense that they are composed of different elements, such as words, categories, and other components (Potter \& Hepburn, 2007) used in retrospective sensemaking accounts. Therefore, discourses are created and maintained through the language use that is involved in retrospective sensemaking accounts.

Accordingly, sensemaking is seen as a constructive practice (Sandberg \& Tsoukas 2015) which includes how "people concerned with 1) identity in the 2) social context of other actors engage 3) ongoing events from which they extract 4) cues and make 5) plausible sense 6) retrospectively while 7) enacting more or less order into these ongoing events" (Weick, 2001, p. 463, numbers and italics added). People constantly engage in making sense of their experiences via these seven interrelated sensemaking properties (Thurlow \& Helms Mills, 2009). Viewed from a sensemaking perspective, "meaning is not 'attached to' the experience that is singled out," but instead, "the meaning is in the kind of attention that is directed to this experience" (Weick 1995, 26).

The sensemaking property of plausibility is essential to understanding why some lived experiences become meaningful for individuals while others do not (Helms Mills et al., 2010). Weick (1995) notes that plausibility, rather than accuracy, drives sensemaking. Plausibility "refers to a sense that one particular meaning is more meaningful than others or that something feels right within the range of possible explanations available to sensemakers in a given situation" (Helms Mills et al., 2010, p. 189). In other words, the plausible explanation needs to resonate with discursive possibilities (Helms Mills et al., 2010). Cornelissen, Clarke \& Cienki (2012) state that, in the process of sensemaking, language can be seen as a resource that individuals use to make novel circumstances understandable: i.e., as a resource for sensemaking. As a result, discourses are constituted from language which, further, is the resource for sensemaking of lived experiences. In this way, discourses not only influence and restrict the possibilities of thought (cf. Helms Mills et al., 2010) but are also formed by language use that is involving in the process of sensemaking.

When we examine the social dimension of the sensemaking of lived experiences, we realize that, even when alone, project participants are in the company of others and their respective cultures (Weick, 1995). Words and dialogs from the surrounding environment infiltrate their thinking, and these words include both the social contexts of their use and historical struggles over connotation (Wetherell, 2007). Lived experiences are thus neither ineffable nor invisible, but built from social practices (cf. Wetherell, 2007). These practices also influence people's ongoing identity construction. 
From the sensemaking point of view, 'individual' is a discursive construction; a sensemaker has many selves, not just one, and these identities are constantly redefined, shaped, and stabilized in the process of interaction (Weick, 1995). In other words, project participants constantly create themselves into existence through the ongoing process of sensemaking. In relation to discourses, project participants make sense of their lived work experiences through identity, after which the enacted meaning then positions them into a certain type of subject position.

Enactment in sensemaking means that people make sense of their experience within their environment. Helms Mills et al. (2010, p. 187) propose that "sensemaking can be either constrained or created by the very environment that it has created." Sensemaking is not about people's external negotiations, but merely people's negotiations about their perceptions of what they have actively put into the environment (Weick, 1979). In each specific context, there is only a limited amount of possible words and discourses through which people can construct meaningful lived experiences (Potter \& Wetherell, 1987). In other words, how participants comprehend their lived experiences of project-based work in the public healthcare context is affected by the sociocultural discursive practices in which they are embedded (Jørgensen \& Phillips, 2002). Everyday language use about project-based work therefore constructs, and continually re-shapes, the understanding of project-based work within public healthcare and, in this way, both maintains the social order or allows for change (Berger \& Luckmann, 1966; Potter \& Wetherell, 1987). In other words, discursive sensemaking practices of project-based work also include social effects, which stem from the project occurring within society (see Gherardi, 2012). The discursive sensemaking perspective considers the retrospective sensemaking accounts and their discursive practices to exist in a reciprocal, cyclical relationship with the context in which they occur, and this 'circuit of reproduction' (Bourdieu, 1977) 'creates and recreates the objectified social structures and the conditions in which it occurs' (Gherardi 2012, p. 168). Such as Gherardi states (2012, p. 168, taking after Foucault, 1982, p. 727), "people know what they are doing, they know why they are doing it, but they don't know what doing it does". This is why it is important to understand what consequences discursive sensemaking accounts have regarding the context in which they occur, as well as what kind of project reality they (re)produce.

\section{Research Aims}

This research aims to interpret the discursive sensemaking of lived experiences in order to provide conceptual and practical knowledge regarding project management within public healthcare. With regard to the discursive sensemaking perspective on project-based work, we highlight the following analytical questions: 
Q1: What kind of utterances do hospital project participants use while making sense of their lived experiences of projectbased work?

Q2: What are the project participants' plausibility strategies for sensemaking (how are the lived experiences made meaningful)?

Q3: How are project participant identities positioned according to these plausibility strategies (what are the effects on subjects)?

Q4: What consequences do the discursive sensemaking accounts have in the context of project-based work in public healthcare?

Q5: In what ways do the discursive sensemaking practices contribute to the production and reproduction of healthcare change project reality?

The first three questions relate to the lived experiences, as well as the strategies of language use through which project participants author meaning to their lived experiences. As was asserted earlier in this article, plausibility has been shown to be an important sensemaking property when considering the discursive environment, and it provides a route for integrating sensemaking and discourses (see Helms Mills et al., 2010). Plausibility strategies are also a way to determine how project participant subjectivities are positioned within a discourse. The fourth and fifth questions are connected to the interpretation of how sensemaking accounts translate into actions.

\section{RESEARCH PROCESS}

\section{Case}

This research studied the case of a change project in its planning phase at the Finnish University Hospital. It is characteristic in Finland that healthcare is a primarily publicly-funded field, which aims to provide universal access to health services and reduce the health inequalities between different population groups. (Ministry of Social Affairs and Health, 2010). The University Hospital under study was owned and funded by the joint authority, which comprises 29 member municipalities, each with their own decision-making bodies that are represented in the Council of the Hospital District. Supreme decision-making power in the joint municipal authority was exercised by the Council. The joint municipal authority under study represents an average authority based on the sizes and populations of the 21 joint municipal authorities in Finland. 
The project under study was chosen because it was a long-lasting, large-scale change project within the healthcare setting that included a diverse array of healthcare professionals from different positions. The purpose of the change project under study was to map and plan a part of a new hospital addition that would unite two of the University hospital's clinics. This included the integration of two clinics and several small hospital wards. The main justification for the hospital addition was that more practical space is necessary to streamline functions and enable present-day medical care. Centralization and spatial reduction were considered necessary to improving patient safety and the quality of treatment. The streamlining of functions was estimated to increase productivity by $10-15 \%$. The construction of the new hospital part would require an investment of approximately 75 million euros. In this study, we concentrated on the planning of the operations and functionality of the new hospital rather than its construction.

The planning and mapping of the addition to the hospital began in the year 2011. At that time, the focus was on mapping the current situation, formulating the future needs to the two united clinics, and outlining a preliminary strategy for how to link the clinics. During this process, the project was further integrated into a larger program that was aimed at renewing and renovating the premises of the whole University hospital. As such, the case project served as the first phase of the larger renewal program.

As a result of the preliminary mapping, the Council decided to begin the planning of the new hospital. The objective of this planning phase was to formulate a project plan for the operative functions based on which the Council would decide whether to continue with the project. The project plan was completed in 11/2014 with permission to continue the planning. During the next step, in which personnel were able to participate in different working groups, the planning of functionality continued. The working method for planning was interactional and action-based, utilizing modern technology as well as a virtual environment. This phase continued until autumn 2016, after which there was a break in the working groups. In 3/2017, the Council made a decision that the new hospital addition will be built.

\section{Data}

We obtained permission from the organization under study to carry out the presented research. Also, we acquired informed consent from each study participant (Denzin \& Lincoln, 2011). We followed the project during the period 5/2015-4/2017. The empirical material used in this study consists of primary material and secondary material. The primary material consists of interviews with 12 project participants. Altogether, there were 17 face-to-face interviews, as five of the project workers were interviewed twice. The interviews lasted approximately one hour each, with a range of 24 to 94 minutes. 
The secondary material consists of two large sets of project plan documents, intranet pages, internet pages, informal conversations with a program manager, as well as different project participants and stakeholders, the PowerPoint presentations of two consultants, observations from two information events, along with the proceedings and annual reports of a hospital district council between the years 2010-2015. The secondary material helped us form an overall picture of the change project as well as the organization under study. In this article, the secondary material has been utilized to form a description of the case.

The criterion for study participation was active participation in the ongoing project, particularly in the mapping, planning and functionality development of the new hospital. The participants were selected using a 'snowball technique' (Denzin \& Lincoln, 2005), in which the first participant was selected on a discretionary basis and was then asked to suggest further participants. The next participants were also asked to suggest suitable study participants. However, we also ensured that the participant pool sufficiently represented both clinics, as well as different professional backgrounds and positions within the project. The study participants included key members, all with healthcare backgrounds, of the project (5 persons), as well as front-line managers from the wards (both from nursing and medicine) who took part in the project through different working groups (7 persons).

The interviews were conducted as open interviews, which means that no structural questions or themes guided the interviews. Thus, regarding data collection, the interviews could be considered to be more conversations than interviews. The participants were asked to describe their role, experiences and thoughts about in the current change project. The interviewer aimed to keep the talk as open as possible by giving participants space and time to reflect and express themselves. (Denzin \& Lincoln, 2011.) The interviewer used certain phrases, such as "That is interesting, could you tell me more about that issue" or "Can you open up that issue more", to get the interviewee to expand on their initial response. The interviewer was also regarded as having an active part in the conservation; it was considered that the interview occurred in a situation in which the positions of the interviewer and the study participant inevitably influenced how the study participants chose to impress themselves. The interview sessions used in this study are considered to be unique, which is a known limitation of the discursive approach, and for this reason, cannot be replicated. The quality criteria for the chosen discursive perspective will be discussed as part of the analysis to limit the constraints that uniqueness places on the study. The interviews were conducted in Finnish, tape-recorded and later transcribed for the analysis.

\section{Analysis}


We divided our analysis into the first and second reading of the data, in which the first reading focused on identifying discursive patterns of sensemaking in lived project work experiences and the second reading explored their effects on the healthcare change project. The first reading aimed to gain insight on how project participants constructed meaningful lived experiences of project-based work - i.e. made sense of them - and investigate the dimensions that made the lived experience seem plausible. The analysis did not focus on the interaction between interviewee and interviewer, but rather the rhetoric through which project participants authored meaning to their lived experiences. Therefore, it was not relevant whether the retrospective accounts were true or not. Rather, the analysis focused on how project participants made sense of their lived work experiences, i.e. their "being-in-the-world" (Heidegger, 1962), within the healthcare change project.

To more profoundly understand how language was involved in the process of sensemaking of lived experiences, we applied the phenomenological thinking presented by Goulding (2003), according to which people approach their world "with a stock of knowledge made up of common sense constructs and categories that are essentially social in action" (Goulding, 2005, p. 301, referring to Schutz, 1967). Although these stocks of knowledge are incomplete and open, they are stable enough to produce familiarity. This dictates that project participants interpretatively apply a category related to the particulars of a situation when describing their lived experiences (Goulding, 2005, referring to Holstein \& Gubrium, 1994). In this context, language functions to describe reality or convey information and, consequently, the meaning of a word is based on what it refers to, stands for, or corresponds to. A degree of commonality also exists, as different people can experience the world in the same way, with the experiences then intersubjectively sharing the same meaning. The fundamental assumption is that "a person's life is a socially constructed totality in which experiences interrelate coherently and meaningfully" (Goulding, 2005, p. 301).

To identify the discursive patterns in retrospective sensemaking accounts of lived project experiences, we utilized Potter's \& Wetherell's (1987) interpretive repertoires as an analytical tool. Interpretive repertoires are "relatively internally consistent, bounded language units" (Potter \& Wetherell, 1987, p. 171) that can be seen "as building blocks speakers use for constructing version of actions, cognitive processes, and other phenomena" (Potter \& Wetherell, 1987, p. 172). Interpretive repertoires thus provide a useful tool for analyzing the polyphony of project participants' sensemaking of their lived project work experiences. In this study, contradictory or even paradoxical interpretive repertoires are considered resources through which actors can seek to understand their lived experiences (see Whittle, 2006). Interpretive repertoires contain the distinct lived experiences, plausibility strategies and identity positioning (see Ball \& Wilson, 2000) of project participants' sensemaking, along with their consequences for the project environment. In the analysis, we 
concentrated on the polyphony of sensemaking of lived experiences to investigate the equivocal ways in which lived experiences are able to come into existence as meaningful and plausible (Q1-Q3), and what functions these different repertoires had (Q4). In addition, we explored how the retrospective sensemaking accounts produce or reproduce the project environment in which they occurred (Q5).

The analysis was an iterative process, which was not conducted linearly. During the preliminary stage of the analysis, the researcher listened to the interview from the tape recorder while simultaneously reading the transcript. This process was done to facilitate an overall understanding of the content of the interview. We then coded the text by identifying and marking parts that included reflexive talk about lived experiences (utterances) of project-based work (Potter \& Wetherell, 1987). At this point, our unit of analysis was neither a word nor a sentence, but rather one complete lived experience from which the illustrative distinct utterances were chosen. During the second phase, we utilized the sensemaking property of plausibility to understand how the sensemaking of lived experiences of project-based work resonates within the discursive context. We investigated what kind of strategies project participants use to make their lived experience of project-based work plausible. We also explored how project participants identities are positioned within these plausibility strategies. These phases were formatted in a way that facilitated the identification of interpretive repertoires that were used to make lived experiences meaningful.

For these phases, we asked the following questions: "How are accounts established as solid, real and stable representations of the project management world?" and "How are people's constructions of the project management world designed so that they appear as stable facts, and how do they undermine alternative versions?” (Jørgensen \& Phillips, 2002). We thus included alternatives for the objectified version of interpretive repertoires, which are often referred to as resistance or deviant cases (Potter, 1996). In this way, we were able to explore how the dominant utterances operates in the interpretive repertoires, i.e. why some discourse became meaningful and plausible while other discourse was not (cf. Thurlow \& Helms Mills 2009). The following simplistic example shows how the analysis proceeded.

It has been extremely comic, and in a way frustrating, that a new consultant will always come along. And they always come with-, they are really pretty or handsome, women are pretty, and men are handsome, they have this perfect surface - and then they are full of emptiness inside. And they only waste our time because they ask us the same questions that we have already thought through, and then they present those things as brilliant conclusions of their own. And they never ever have ideas of their own; they are not able to do that because they do not know or understand [our processes]. I do not understand their role. It is so depressing.

The extract contains utterances (Q1) such as 'comic', 'frustrating' and 'depressing' that refer to lived experiences. Other utterances, such as 'I do not understand', reflect the way the interviewee strives to author meaning to her/his lived 
experience of project-based work in a hospital. The interviewee brings her/his lived experience of consultants in change projects into existence by considering the lived experience senseless. The interviewee explicitly aims to prove (Q2, a strategy) to the interviewer that he/she heavily disapproves of the utilization of consults in hospital change projects instead of healthcare professionals. The interviewee positions her-/himself as an expert in relation to consultants (Q3). Consequently, the interviewee resists organizational chance. Furthermore, the rhetorical strategy represents an alternative discourse (resistance) to the common top-down organizational change management practice (Q4).

The 'stages' of analysis did not form a linear process, but rather mainly emerged as interrelated and simultaneous. A pattern slowly began to emerge after the interviews had been read through in detail several times. Ultimately, six interpretive repertoires that added unique perspectives to the research questions: 1) repertoire of transformation, 2) repertoire of realism, 3) repertoire of politics, 4) repertoire of individuality, 5) repertoire of reflexivity and 6) repertoire of senselessness. Each of these six repertoires were found in the interviews of both key people and other project participants. We will present a detailed analysis of the six repertoires in the results section and the composition of these repertoires are presented in Table 1 .

Table 1. The composition of interpretive repertoires through which project participants made sense of their lived experiences of project-based work in a public health care change project.

\begin{tabular}{|c|c|c|c|c|}
\hline & $\begin{array}{l}\text { Distinctive } \\
\text { utterances } \\
\text { (examples) }\end{array}$ & $\begin{array}{l}\text { Plausibility } \\
\text { strategies }\end{array}$ & $\begin{array}{l}\text { Constructed } \\
\text { identity }\end{array}$ & Effects \\
\hline $\begin{array}{l}\text { Repertoire of } \\
\text { Transformation }\end{array}$ & $\begin{array}{l}\text { 'learning' } \\
\text { 'development' } \\
\text { 'increased } \\
\text { understanding / } \\
\text { leadership skills' } \\
\text { 'new perspectives' } \\
\text { 'motivating' } \\
\text { 'opportunity' } \\
\text { 'professional } \\
\text { growth' } \\
\text { 'understanding } \\
\text { bigger picture' }\end{array}$ & $\begin{array}{l}\text { Project-based } \\
\text { work enables } \\
\text { personal and } \\
\text { organizational } \\
\text { level } \\
\text { transformation }\end{array}$ & $\begin{array}{l}\text { Noble, } \\
\text { distinguished, } \\
\text { responsible and } \\
\text { developing } \\
\text { employee }\end{array}$ & $\begin{array}{l}\text { Produces project- } \\
\text { based work worth } \\
\text { pursuing }\end{array}$ \\
\hline $\begin{array}{l}\text { Repertoire of } \\
\text { Realism }\end{array}$ & $\begin{array}{l}\text { 'challenging' } \\
\text { 'pressure is getting } \\
\text { to me' } \\
\text { 'I don't have any } \\
\text { peace to do my } \\
\text { work' } \\
\text { 'long working hours' }\end{array}$ & $\begin{array}{l}\text { Difficult and } \\
\text { unsustainable } \\
\text { working conditions } \\
\text { are part of project- } \\
\text { based work and } \\
\text { need to be } \\
\text { endured }\end{array}$ & $\begin{array}{l}\text { Real life project } \\
\text { laborer }\end{array}$ & $\begin{array}{l}\text { Maintains the } \\
\text { unsustainable } \\
\text { practices in project- } \\
\text { based work }\end{array}$ \\
\hline $\begin{array}{l}\text { Repertoire of } \\
\text { Politics }\end{array}$ & $\begin{array}{l}\text { 'influencing' } \\
\text { 'lobbying' } \\
\text { 'authority' } \\
\text { 'struggles' } \\
\text { 'questioning' }\end{array}$ & $\begin{array}{l}\text { Competition } \\
\text { is an inherent part } \\
\text { of project- } \\
\text { based work }\end{array}$ & Tough survivor & $\begin{array}{l}\text { Maintains the } \\
\text { boundaries between } \\
\text { different parties }\end{array}$ \\
\hline
\end{tabular}




\begin{tabular}{|l|l|l|l|l|}
\hline $\begin{array}{l}\text { Repertoire of } \\
\text { Individuality }\end{array}$ & $\begin{array}{l}\text { 'requires extreme } \\
\text { resilience' } \\
\text { 'you need to have } \\
\text { stamina' } \\
\text { 'you need to be } \\
\text { bold' }\end{array}$ & $\begin{array}{l}\text { Project-based } \\
\text { work requires } \\
\text { certain personal } \\
\text { qualities due to } \\
\text { nature of project- } \\
\text { based work }\end{array}$ & $\begin{array}{l}\text { Resilient and } \\
\text { hypermuscular' } \\
\text { employee }\end{array}$ & $\begin{array}{l}\text { Emphasizes skills } \\
\text { and competences }\end{array}$ \\
\hline $\begin{array}{l}\text { Repertoire of } \\
\text { Reflexivity }\end{array}$ & $\begin{array}{l}\text { 'they really want to } \\
\text { hear what you have } \\
\text { to say' } \\
\text { 'everybody is } \\
\text { allowed to talk' } \\
\text { 'patients point of } \\
\text { view' }\end{array}$ & $\begin{array}{l}\text { Project-based } \\
\text { supports both } \\
\text { polyphony and the } \\
\text { critical evaluation } \\
\text { of functions and } \\
\text { processes }\end{array}$ & Idealist & $\begin{array}{l}\text { Aims for diversity and } \\
\text { receptiveness }\end{array}$ \\
\hline $\begin{array}{l}\text { Repertoire of } \\
\text { Senselessness }\end{array}$ & $\begin{array}{l}\text { 'prison' } \\
\text { 'mission impossible' } \\
\text { 'strong } \\
\text { contradiction' }\end{array}$ & $\begin{array}{l}\text { Project-based } \\
\text { work includes } \\
\text { pointless control }\end{array}$ & Contested experts & $\begin{array}{l}\text { Resists the current } \\
\text { unsustainable } \\
\text { project-based work } \\
\text { and considers the } \\
\text { actualization of } \\
\text { 'I hate this' } \\
\text { impossinant talk }\end{array}$ \\
\hline
\end{tabular}

As is characteristic of discursive studies, a variety of quality arguments have been presented. For this analysis, we adopted the most established criteria (c.f. Pietiläinen \& Salmi, 2017). First, we aimed at internal coherence, which entails identifying and formulating consistent interpretive repertoires from the data (Georgaca \& Avdi, 2012). We utilized the participants' orientation (Potter \& Wetherell, 1987) to ensure internal coherence; in this way, we assessed whether the project participants were able to address different repertoires, which would prove that the repertoires had a strong cultural basis. We searched for utterances such as 'on the other hand', 'however' or other terms with a similar effect; all of these are a typical manifestation of the ability to differentiate between different repertoires (Potter \& Wetherell, 1987). Secondly, we paid attention to the diversity of data and richness in detail so that we could demonstrate the polyphony of the studied lived experiences (Georgaca \& Avdi, 2012). To achieve this goal, we strived to identify coherent interpretive repertoires and, at the same time, paid attention to the resistance and alternative versions of lived experiences. Thirdly, we strived to present both our research process and the analysis as transparently as possible so that a diverse audience of readers could judge the quality of our findings (Georgaca \& Avdi, 2012). The extracts are justified examples, as they will illustrate the contents and dynamics of lived experiences that relate to each repertoire. Lastly, we employed the discursive sensemaking perspective with the specific goal of providing new theoretical insights for change project management within a public healthcare context that are applicable in real-world situations (Georgaca \& Avdi, 2012).

After identifying various interpretive repertoires and their patterns in the data, we proceeded to the second reading of the data, in which we concentrated on the relationships between repertoires (Q5). In other words, we scrutinized the results of the first reading in light of the following question: "How do these repertoires affect the public healthcare change project 
reality, what is emphasized and what is marginalized?" As a result, we found that retrospective sensemaking accounts of project participants' lived experiences, when considered through distinct repertoires, either legitimize project-based work in bringing about change in public healthcare (repertoires of transformation and individuality), take for granted suppressive dimensions of project-based work (repertoires of realism and politics), or provide an alternative version of the management of public healthcare change projects (repertoires of reflexivity and senselessness). The results of the second reading, along with their practical relevance, are further reflected upon in the discussion section.

With regard to the authors, it is reasonable to note that the first author, who conducted both the interviews and their transcriptions as well as the analysis, was familiar with the organization under study as she had had a post there (albeit as a healthcare professional and not at the clinics that were being united). As such, she viewed and interpreted the material from the position of a former healthcare professional from the organization under study and as a novice health administration researcher.

\section{RESULTS}

\section{Discursive sensemaking of project-based work in public healthcare}

\section{Repertoire of Transformation}

When authoring meaning to their lived experiences through the repertoire of transformation, project participants used utterances such as 'learning', 'opportunity' or 'motivating'. Project-based work was experienced as meaningful because it increased leadership skills as well as the understanding of an employee's function and the 'bigger picture'. Also, projectbased work put employees in contact with important people that were considered authorized, for example, national-level experts or international collaborators.

It [working in this particular project] has increased my understanding and leadership skills; also, as there are many hospital construction projects going on [in Finland] I have really gained an understanding of these [processes] through this [project].

(Interview 3)

I have gained new perspective and, in a way, have had a wake-up call concerning what we could and should take into account [concerning operation/function]

(Interview 8)

It is very motivating that I am allowed to work with different kinds of individuals throughout our hospital, as well as with all kinds of top experts from Finland who are taking part in this project.

(Interview 9)

I would say that it is rare to be able to take part in this kind of project in one's working career. This is a perfect closure.

(Interview 15) 
The ongoing project was characteristically argued to be an opportunity to take part in important and visible work that has a major societal impact (interview 15). The project-based work was considered eligible - it was regarded as a means to increase one's social reputation in a good way. The interviewees emphasized opportunities for personal learning (interview 8), as well as the possibility to develop the organization and comprehend wider development trajectories revolving around public health care (interview 3). Furthermore, projects were considered as a way of strengthening one's own professional network (interview 9). Project participants authored plausibility for their lived experiences through ideas that are typical of transformation on both personal and organizational levels.

Within this repertoire, project participant identity was positioned as noble and distinguished employees who take responsibility for their continuous development to meet the demands of working life. The interviews showed that project participants maintained ideas that a project worker is responsible for her/his professional development. As a dominant view, project-based work enabled employees to experience something else than normal, perfunctory work and, in this way, provided opportunities for professional growth. This repertoire described project-based work in a hospital as important, respected and worth pursuing while rejecting the idea that projects could negatively affect employees through increased strain or competition.

\section{Repertoire of Realism}

The repertoire of realism represented the dominant discourse among project participants. Compared to the repertoire of transformation, this repertoire constructed a different kind of landscape for the lived experiences of project-based work. It brought project workers from the lofty dimensions of transformation back to the reality.

It was challenging to work with these consultants. We had to check the numbers because they were partially wrong as they [the consultants] did not understand our function or processes. Therefore, some numbers did not belong there and some numbers were missing. It was challenging.

(Interview 4)

I feel that at this point the pressure is really getting to me, as it is time to show what we have accomplished and if we have actually achieved anything concrete.

(Interview 6)

When we conducted the project plan, we had very long working days. After our regular working hours, we stayed here and searched through different kinds of statistics and did the work together.

(Interview 2)

I often feel that I do not have any kind of peace to do my work. All the time someone pecks at you, and you need to report everything - every phone call, what did you talk about - to the management. It is this hierarchy in decision-making. I think that it makes everything 'sticky' and slow... I often wonder why 
reasonable talk is not heard - although I am sure it is, I am not saying that anybody is stupid or obstinate, but it just needs it's own, slow protocol.

(Interview 1)

In this repertoire, project participants used utterances such as 'time pressures', 'insufficient resources', 'the lack of autonomy', 'feelings of inadequately' as well as 'constant insecurity' when making sense of their lived experiences. The interviewees mentioned a pressure to achieve project goals (interview 6) and certain challenges regarding decisionmaking in healthcare projects (interview 1). Within this repertoire, consultants were presented as insufficient agents whose work constantly needed to be 'double-checked' (interview 4). Working with consultants were expressed as challenging (interview 4). Project-based work was regarded to include long working hours in addition to the project participants' own working tasks (interview 2).

To make these lived experiences seem plausible, project participants regarded the reality of project-based work both as something that belongs to healthcare projects as well as something that needs to be endured. In this way, project participant identity was positioned as real-life project laborer. The language use through this repertoire maintained unsustainable practices in project-based work in public healthcare change project, and did not support alternative working conditions within a healthcare project.

This repertoire was, in many ways, the opposite of the repertoire of transformation. Project workers also recognized this contradiction, which can be noted at the end of the last extract through the utterance of although. In this way, the project worker admits that she/he realizes that the ideal dimensions of project-based work are mainly utopic and not a result of anyone's incompetence. This orientation can be seen as a way to control different, conflicting repertoires, as well as to make sense of the conflicts between the real-life experience and the ideals of project-based work.

\section{Repertoire of Politics}

The repertoire of politics came close to the repertoire of realism; however, it was characterized by a different tone. From the perspective of politics, utterances such as 'influencing' and 'lobbying' were used when making sense of lived experiences of project-based work.

In the beginning, I experienced a lack [of support]. Our senior medical officer was not taking part in the project at that time, and even though I do understand the obstacles and many duties of the senior medical officer, I somehow experienced that she/he was such an outsider and uh ... with the special physician, we conveyed to her/him that we do need strong support, which we didn't have-, we experienced that we didn't have enough authority.

(Interview 2) 
Well, there are struggles arising from this [part of the new hospital] being built first, and then others from different parts of the hospital are 'morose' because they have to plan their operational functions based on our new operational functions.

(Interview 1)

Back then, I really questioned why we need to use the term expert physician [in this project]; it should be planning expert... I look at the things from the nursing perspective, and therefore I always have to- it would be the same if the ward nurse were called expert ward nurse.

(Interview 5)

The presence and support of authorities - such as senior medical officers - was mentioned as important to achieving the desired goals (interview 2). Collaborative work between different wards or parts of the hospital was presented as challenging (interview 1), with interviewees highlighting tension between the professions - nurses and physicians - that dominate the hospital setting (interview 5). Project-based work was experienced a form of survival, and different alliances and strategies were considered to be important to the eventual success of the project.

These lived experiences were made plausible by regarding that competition is a natural part of project-based work within public healthcare. Moreover, the project was considered an arena in which the strongest and most competitive individuals would be successful. Successful project worker identity was positioned as tough survivor and/or warrior. Sensemaking of lived experiences of project-based work in healthcare through this repertoire highlighted the boundaries between different parties: between different units and wards, between key people in the project and hospital management, between project participants and the key people, as well as between different professions. Furthermore, the accounts of lived experiences diminished the importance of collaborative work within public healthcare change projects.

\section{Repertoire of Individuality}

The repertoire of individuality was another repertoire that illustrated dominant project management utterances in the healthcare setting. Project participants used utterances such as 'resilience', 'you need to have stamina' or 'you need to be bold' when making sense of the lived experiences of project-based work.

It [project-based work] requires extreme resilience; I mean that you need to talk over the things again and again and again and again and again. I just laughed that I am like an evangelist, always in a new place. And no, you can never think that I have already said this, but you need to go and go and go.

(Interview 10)

You just need to have the stamina to bring forth new ideas and things, and you need to be bold because if you do not have the courage to do that - well, then nothing will change.

(Interview 6) 
Project-based work was argued to include hard work that requires a strong focus, goal orientation and the ability to tolerate pressure (interview 10). Furthermore, it became clear that the achievement of project goals could only be possible through a strong commitment from the project participants (interviews 10 and 6). While the repertoire of realism viewed projectbased work in a negative light, as well as something that individual project workers need to endure, sensemaking through the repertoire of individuality constructed project-based work as plausible by regarding it as individual-level accomplishments.

A good and competent project worker was perceived as a resilient and sacrificing employee who is willing to give her/his best for the sake of the project. Within this repertoire, project participant identity was positioned as an independent subject who is resilient and 'hypermuscular'. The success of a project was considered to depend on the quality of the individuals who took part in the project, i.e. their skills and competences, while difficult and stressful working conditions were neglected.

\section{Repertoire of Reflexivity}

The repertoire of reflexivity represents an alternative discourse regarding change projects in public healthcare. Project participants used utterances such as 'they really want to hear you', 'everybody is allowed to talk', 'for the best of the people' or 'patient orientation' when making sense of their lived experiences through this repertoire.

I have experienced these working groups as extremely fruitful. It can be seen that they [consultants] are not doing this for the first time. They [ask], 'please can you repeat what you said, can you specify it in more detail', somehow they make you feel as though they really want to hear what you have to say, they really focus [on you], it really feels that you are heard.

(Interview 2)

In there [working groups], everybody is allowed to speak, I feel that they- I have felt that because they [consultants] are outsiders [from the hospitals] that they have facilitated-, the issue might be that because I belong to the hospital staff and am working here and if you are representing this hospital the other [project] participants do not take your ideas as seriously as if you are outsider, even though the idea itself was the same.

(Interview 6)

I feel that the most important thing in this project is the patient. We are not constructing this new hospital or developing new processes for the staff but for the best of the people [living in this area], and that we will plan a good and functional hospital for them.

(Interview 8)

Within this repertoire, the consultant's role was argued to be relevant. The role of consultants was described as reasonable because they were 'outsiders' and were, therefore, able to question the current thinking (interview 6). The project 
participants expressed that consultants improve participation in project-based work in a way that everybody's voice is heard (interview 2).

Project-based work was stated - in an idealistic manner - to take into account different ideas equally and in an supportive way, for example, to enhance patient orientation (interview 8). These experiences of project-based work were authored plausible by considering projects as an arena for polyphony in which members are also allowed to critically evaluate current functions or processes. Drawing from this repertoire, the project worker identity was positioned as an idealist who could bring about sustainable and patient-orientated changes in a public hospital. Discursive sensemaking practices under the scope of this repertoire aimed at diversity and receptiveness in a public hospital change process, a finding that provides an alternative to the traditional project management perspective.

\section{Repertoire of Senselessness}

The repertoire of senselessness offered yet another alternative for how participants author meaning to their lived experiences of project work. Project participants used utterances such as 'mission impossible', 'I don't understand', 'strong contradiction' or 'no extra value' while making sense of their lived experiences of project-based work.

So much money has been wasted on these consultants who bring no value [for this project]. If they would do some real work in this world, but no, and we believe in these consultants. We believe these dudes who came and say 'hey, tell me your process'. I have calculated all the numbers, and I know our operation. They have given no extra value for the project...this is what I call a contemporary [development] process, which involves so called pseudo-projects... at the beginning there was [development], but now they are just trying to adapt us to worse [situation].

(Interview 10)

They have been told that they are all together in this prison [change project] and they just have to defend it [the new hospital] even though they no longer believe in it themselves ... I think that the fundamental problem is the fact that the budget is so tight. Even though they [management of the hospital] are talking about functionality and that the planning is conducted on the basis of functionality, in reality the budget tells us what we can do..... I wish there is a child somewhere who would tell that the Emperor has no clothes.

(Interview 14)

I feel that this has been a mission impossible. That we have had to plan the functionality in too small of a frame that was given to us from above [budget]. And this frame is something that cannot be negotiated. I feel that this has been extremely difficult. I feel that this [new hospital] is going to be too small and not functional, and I hate to be a part of this. At the same time, the staff is resisting, and I have to calm them down even though I feel the same, there is such a strong contradiction.

(Interview 16)

Project participants expressed that project workers are regarded like prisoners (interview 14), trapped in their current positions and roles in the project (interview 16). Project participants argued that they were not able to genuinely take part 
in developing functionality because of the strict budget - even though interactive collaboration was set as a principle of the change project (interviews 14 and 16). The reality of project-based work was regarded as contradictory to the information received from the hospital's top (interview 14). The change project was noted as a 'pseudo project' that actually prepared the employees for organizational downsizing (interview 10). Also, practices that were procured from the private sector, such as the utilization of consultants, were explicitly questioned and consultants were viewed as outsiders who did not understand hospital processes (interview 10). Project participants felt powerless towards the existing practices of project-based work and also experienced themselves as puppets who had to play their part in the project.

The project participants considered project-based work 'senseless' in many ways, i.e. they were not able to author plausibility to it. Project participant identity was positioned as contested experts who actively question the decisions of top management. The repertoire of senselessness embodied resistance towards the actualizations of the repertoires of realism and individuality, providing yet another alternative to the traditional project management perspective.

\section{DISCUSSION}

\section{Effects on the healthcare change project reality}

This article applied a discursive sensemaking perspective to investigate lived experiences of project-based work within a public healthcare change project. During the analysis phase, the first reading of the data identified six distinct sensemaking repertoires (illustrated by utterances of sensemaking of lived-experiences, plausibility strategies, identity positioning as well as functions and consequences), while the second reading proposed how these discursive sensemaking practices affect phenomena related to the concept of a 'public healthcare change project'. The second reading showed that discursive sensemaking practices legitimized traditional project management as a tool for organizational change in the context of public health care, took for granted the unsustainable project work practices and competition that arise during healthcare change projects and offered participants alternative ways to author meaningful lived experiences by either bringing forth public receptiveness or resisting project management practices in the context of public healthcare. We elaborate these aspects in the following.

The repertoires of transformation and individuality, which demonstrated an organizational effect, resonated well with contemporary project management discourses (c.f. Sjöblom et al., 2013) that emphasize aspects such as learning (Lunkka \& Suhonen, 2015) and knowledge improvement (Lindner \& Wald, 2011). Sensemaking of lived experiences through these repertoires emphasized both individual and organizational level transformation and considered the change project 
to consist of individual-level accomplishments. The utterances noted for these repertoires characterized project-based work as worthwhile from both the individual and organizational point of view. The lived experiences that were authored using these repertoires presented project-based work in public healthcare, as well as the project members, in a favorable light. Sensemaking of lived experiences within these repertoires can be interpreted as legitimizing the contemporary project management discourse as a means for organizational change in public healthcare. However, it is important to note that legitimizing traditional project management discourse based on project success as a result of individual actions involves the danger of providing individual-level answers to socio-cultural challenges (cf. Cicmil \& Hodgson, 2006).

We also noticed that project participants' sensemaking of lived project work experiences through the repertoires of realism and politics embodied suppressed and negative dimensions regarding project-based work in a public healthcare. Along with competition, unsustainable and challenging working conditions were considered an inherent part of project-based work in public healthcare. In line with earlier studies (Lindgren et al., 2014; Hodgson \& Cicmil, 2007), these experiences were regarded as something that is unavoidable and needs to be endured. These discursive sensemaking practices both maintained and naturalized the unsustainable practices and boundaries between different parties that exist in public healthcare change projects. We contend that these negative dimensions and unsustainable working conditions were a taken-for-granted aspect in public healthcare change projects.

An alternative way for project participants to make sense of their lived project work experiences was to consider projectbased work as a vehicle for reflexivity. In other words, projects can be considered equivocal means for organizational change to enhance diversity as well as public receptiveness. Interestingly, not many participants included this perspective in their sensemaking of lived project work experiences. Another way for project participants to make sense of their lived experiences of project work was to author them senseless. These discursive sensemaking practices explicitly resisted certain project management practices that occur in healthcare change projects. The project workers voiced concerns that the opinions they voiced were not being heard. The results of this article are condensed in Figure 1, which concisely illustrates project participants' discursive sensemaking of their lived experiences of project-based work in a public healthcare change project context. 


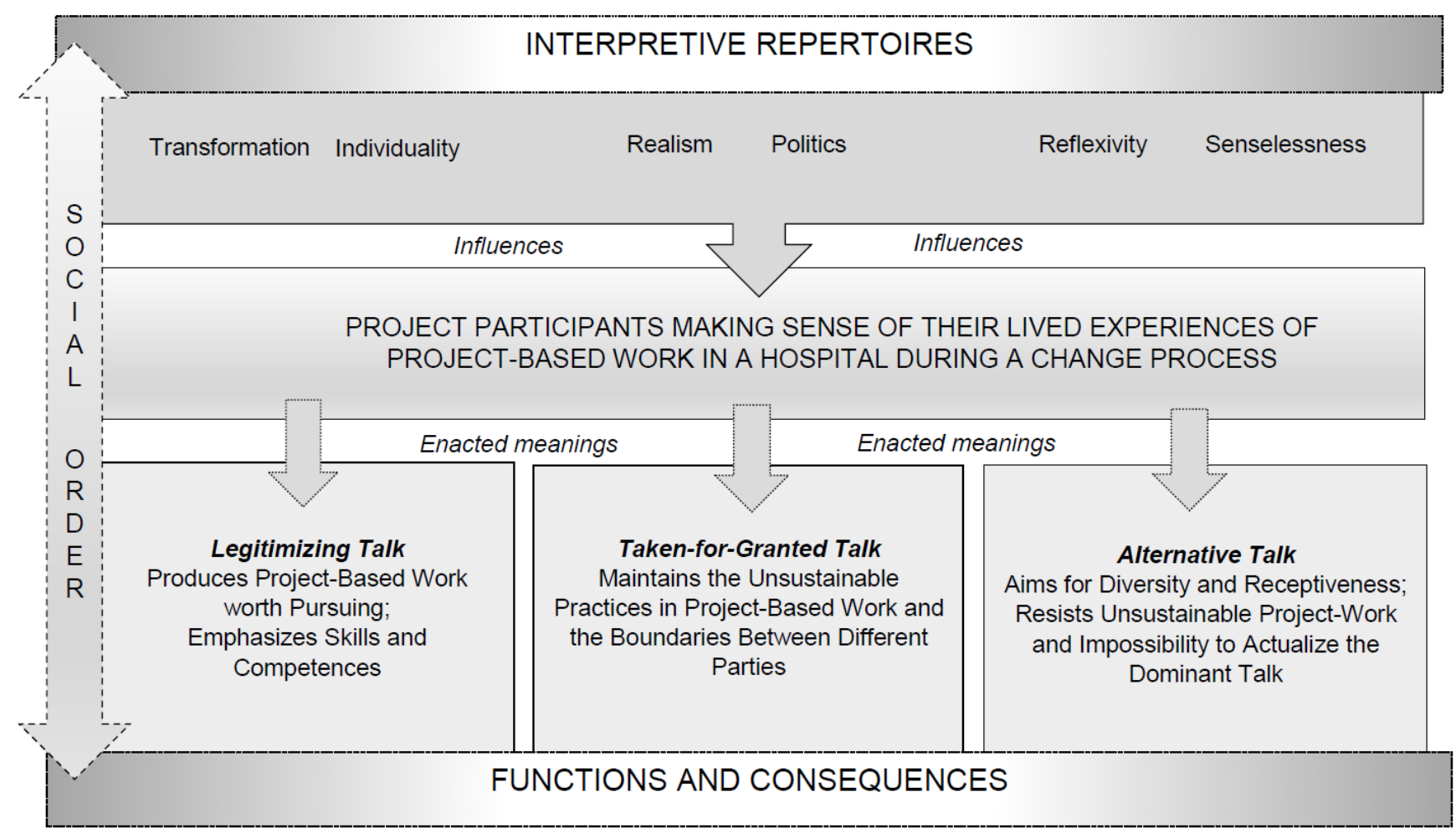

Figure 1. Project participants' sensemaking of lived experiences of project-based work in a hospital during a change process, along with its functions.

Naturalizing challenging working conditions in public healthcare change projects may affect individual project workers because it can shift the focus from unsustainable working conditions towards the individuals and their capabilities. In this way, this practice involves the palpable danger that managers will consider that the people rather than the working conditions need to be changed if things do not work. Moreover, this may lead to unnecessary feelings of inferiority at the individual level, which can subsequently result in project workers burdening themselves with excessive workloads. The results thus indicate that it is necessary to take the wellbeing of project participants seriously within the public healthcare sector. Furthermore, when healthcare organizations utilize projects to bring about change, the ensuring of adequate resources is vital to sustainable project-based work (cf. Cicmil et al., 2016).

The results also indicate that hierarchical professions (see e.g., San Martin-Rodriguez et al., 2005; Bate, 2000), as well as competition between wards and clinics, challenged project-based work in a public healthcare change project. In this way, the results do not support earlier studies that propose that projects provide opportunities for collaboration (Lunkka \& Suhonen, 2015) or more flexible and efficient alternatives to traditional bureaucratic forms of organizing (c.f. Sjöblom et al., 2013). On the contrary, this research showed that project participants considered collaboration to be challenging 
and project-based work was merely realized as a tool for managerial control. The results thus indicate that intraorganizational change project in a public hospital may increase rather than decrease bureaucracy.

In addition, the results of this study show the contradiction between legitimizing traditional project management discourse and taking for granted the unsustainable working conditions as well as boundary-work between different parties. However, project workers were also able to recognize these paradoxical repertoires and, in many occasions, could distinguish between them. However, a remarkable risk for professional role conflicts arises if project workers are unable to differentiate these separate repertoires and create coherent sense between them. In addition, project participants' expectations of participation were in strong conflict with the actual practices of project-based work and, for this reason, the plausibility of the project-based work suffered. This indicates that good communication is important if the project manager wants to keep expectations and actual practices in line, i.e. 'promise what you can provide'.

Interestingly, public receptiveness was only marginally mentioned even though the ideas of receptiveness and equality are core principals of public healthcare. Project-based work with the end goal of streamlining intra-organizational functions and processes, rather than improving public receptiveness, was considered a meaningful part of the healthcare change project. In other words, the results of this study suggest that intra-organizational change projects in public healthcare setting are easily considered as tools for streamlining intra-organizational processes (c.f. Jensen et al., 2013) rather than enablers of public receptiveness. It is important for project managers as well as the upper management in healthcare organizations to realize that traditional project management discourse might shift the focus of change projects from public healthcare premises to, for example, intra-organizational productivity.

In addition, rationality was an aspect that was not identified from the project participants' interviews. Instead of adventure under rational control (Lindgren et al., 2014), project-based work realized itself as a confusing and messy process in which workers needed alliances and politics to survive. Within the identified repertoires, consultants were either considered enhancers of participation (legitimizing talk) or henchmen of the hospital's upper management (resistance). The role of henchmen was not perceived as plausible, and therefore, this role did not make sense for the project participants. The results indicate that in healthcare change projects consultants should be used carefully as agents for topdown change. Consultants might be most suitable as facilitators of genuine multidisciplinary, enablers of diversity, or reducers of competition. 
The wide spectrum of repertoires identified in the interviews implies that project-based work is connected to conventional understandings of working life and organizations. In this way, project-based work is linked to the wider socio-cultural environment in which it occurs. These cultural conventions define positive and negative perceptions of project-based work and thus, reflect how the general morality of work is understood.

\section{Conclusion}

The results of this article demonstrate that the discursive sensemaking perspective provides a relevant approach for studying public healthcare projects and their management as it reveals how the reality of healthcare change projects comprises lived experiences that cannot be reached with positivist scientific research. Lived experiences of project-based work do not occur in a vacuum but are shaped by the context in which they occur. The discursive sensemaking perspective offers a conceptual framework to capture this context and can help dismantle the different processes that comprise the lived experiences of project participants. In this way, it can be leveraged to profoundly understand the praxis of healthcare change projects, i.e. the inseparability and reciprocal relation between individual and the project context. Furthermore, it allows the consequences of the enacted meanings to be assessed and, in this way, can be used to elaborate how sensemaking of lived experiences contributes to social order. It is equally important to understand that the discursive sensemaking perspective does not, however, offer a suitable tool for gaining universal or generalized knowledge about project-based work or project management.

This article showed how the reality of project-based work in a large-scale public healthcare change project differed from the project workers' expectations. It is hence important for project managers in public healthcare projects, and especially relevant for the upper management, to critically evaluate the practices being exercised in project-based work and to understand that public healthcare is a unique context for intra-organizational change projects. Projects will not enhance multidisciplinarity and collaboration unless the various dimensions of project-based work are taken into account and emphasized in practice. It is important to strive to enable participation and find the ways to diminish the competition between different stakeholders. Otherwise, the high expectations of project-based work among project participants may easily turn to the frustration that will not progress the change project. The results of this article can be used to improve project management practices within public healthcare in a way that will not only foster sustainable working conditions, but also proficient change processes. 
The approach used in the presented research can also be applied to sectors or industries other than healthcare. The interpretive repertoires presented in this article show that project-based work and project management in public healthcare share similarities with general project management discourse. At the same time, several distinct features - such as strong professionalism - may challenge large, intra-organizational change project management specifically in the public healthcare setting. For future studies, it would be reasonable to focus particularly on the healthcare professionals' identity work in public healthcare change projects. It would also be useful to focus on the different dimensions that might interfere with the creation of repertoires themselves, for example, organizational roles and functions. This would enhance our understanding of the complex nature of project-based work within public healthcare. Furthermore, the repertoire of reflexivity offers an interesting avenue for further research in public healthcare projects. 


\section{REFERENCES}

Alvesson, M., \& Kärreman, D. (2000). Varieties of discourse: On the study of organizations through discourse analysis. Human Relation, 53(9), 1123-1149.

Aubry, M., \& Lavoie-Tremblay, M. (2018). Rethinking organizational design for managing multiple projects. International Journal of Project Management, 36(1), 12-26.

Aubry, M., Richer, M.-C., \& Lavoie-Tremblay, M. (2014). Governance performance in complex environment: The case of a major transformation in a university hospital. International Journal of Project Management, 32(8), 13331345.

Ball, K., \& Wilson, D. C. (2000). Power, control and computer-based performance monitoring: Repertoires, resistance and subjectivities. Organization Studies, 21(3), 539-565.

Bate, P. (2000). Changing the culture of a hospital: from hierarchy to networked community. Public Administration, 78(3), 485-512.

Bender, M., Connelly, C. D., \& Brown, C. (2013). Interdisciplinary collaboration: the role of the clinical nurse leader. Journal of Nursing Management, 21(1), 165-174.

Berger, P., \& Luckmann, T. (1966). The Social Construction of Reality: A Treatise in the Sociology of Knowledge. Garden City, NY: Anchor Books.

Bettis, P.J., \& Gregson, J.A. (2001). The why of quantitative and qualitative research: Paradigmatic and pragmatic considerations. In E.I. Farmer and J.W. Rojewski (Eds.), Research Pathways: Writing Professional Papers, Theses, and Dissertations in Workforce Education (pp.1-21). Lanham, Maryland: University Press of America, Inc.

Billig, M. (2009). Discursive psychology, rhetoric and the issue of agency. Semen (Online), 27. Retrieved from: http://semen.revues.org/8930, accessed 8.11.2016.

Bourdieu, P. (1977). Outline of a theory of practice. Cambridge, New York, Melbourne, Madrid, Cape Town, Singapore, Sao Paolo, Delhi, New Mexico: Cambridge University Press.

Brown, A., Colville, I., \& Pye, A. (2015). Making sense of sensemaking in organization studies. Organization Studies, $36(2), 265-277$.

Cicmil, S., \& Hodgson, D. (2006). Making projects critical: an introduction. In D. Hodgson \& S. Cicmil (Eds.), Making Projects Critical (pp. 1-25). London, United Kingdom: Palgrave Macmillan.

Cicmil, S., Williams, T., Thomas, J., \& Hodgson, D. (2006). Rethinking project management: Researching the actuality of projects. International Journal of Project Management 24(8), 675-686.

Cicmil, S., Lindgren, M., \& Packendorff, J. (2016). The project (management) discourse and its consequences: On vulnerability and unsustainability in project-based work. New Technology Work and Employment, 31(1): 58- 76.

Cornelissen, J. P., Clarke, J. S., \& Cienki, A. (2012). Sensegiving in entrepreneurial contexts: The use of metaphors in speech and gesture to gain and sustain support for novel business ventures. International Small Business Journal, 30(3): 213-241.

Crawford L, Aitken, A., \& Hassner-Nahmias, A. (2014). Project Management and Organizational Change. Pennsylvania: Project Management Institute, Inc.

Denzin, N. K., \& Lincoln, Y. S. (2005). The SAGE Handbook of Qualitative Research. Los Angeles, CA: Sage Publications. 
Denzin, N. K., \& Lincoln, Y. S. (2011). The SAGE Handbook of Qualitative Research. Los Angeles, CA: Sage Publications.

Foucault, M. (1976). The history of sexuality: Volume 1. New York: Pantheon.

Foucault, M. (1980). Power/knowledge. Selected interviews and other writings 1972-1977. New York: Pantheon.

Georgaca, E., \& Avdi, E. (2012). Discourse analysis. In A. Thomson \& D. J. Harper (Eds.), Qualitative Research Methods in Mental Health and Psychotherapy: A Guide for Students and Practitioners (pp. 147-162).

Chichester, United Kingdom: Wiley.

Geraldi, J., \& Söderlund, J. (2018). Project studies: What it is, where it is going. International Journal of Project Management, 36(1), 55-70.

Gheraldi, S. (2012). How to Conduct a Practice-based Study: Problems and Methods. Cheltenham, UK, Northampton, MA, USA: Edward Elgar Publishing.

Goulding, C. (2005). Grounded theory, ethnography and phenomenology: A comparative analysis of three qualitative strategies for marketing research. European Journal of Marketing, 39(3/4), 294-308.

Heidegger, M. (1962). Being and Time. Oxford, United Kingdom: Basil Blackwell.

Helms Mills, J., Thurlow, A., \& Mills, A. (2010). Making sense of sensemaking: the critical sensemaking approach. Qualitative Research in Organizations and Management: An International Journal, 5(2): 182-195.

Hodgson, D., \& Cicmil, S. (2006). Are projects real? The PMBOK and the legitimation of project management knowledge. In D. Hodgson \& S. Cicmil (Eds.), Making Projects Critical (pp. 29-50). London, United Kingdom: Palgrave Macmillan.

Hodgson, D., \& Cicmil, S. (2007). The politics of standards in modern management: Making 'the project' a reality. Journal of Management Studies, 44(3): 431-450.

Hodgson, D., Paton, S., \& Cicmil, S. (2011). Great expectations and hard times: The paradoxical experiences of the engineer as project manager. International Journal of Project Management, 29(4): 374-382.

Holstein, J., \& Gubrium, J. (1994). Phenomenology, ethnography and interpretative practice. In Denzin, N. \& Lincoln, Y. (Eds), Handbook of Qualitative Research. Thousand Oaks, CA: Sage.

Jensen, C., Johansson, S., \& Löfström, M. (2013). The project organization as a policy tool implementing welfare reforms in public sector. International Journal of Health Care Planning and Management, 28(1): 122-137.

Jordan, M. E., Lanham, H. J., Crabtree, B. F., Nutting, P. A., Miller, W. L., Stange, K. C., \& McDaniel R. R. Jr. (2009). The role of conversation in health care interventions: Enabling sensemaking and learning. Implementation Science, 4(15), doi: 10.1186/1748-5908-4-15.

Jørgensen, M., \& Phillips, L. (2002). Discourse Analysis as Theory and Method. Thousand Oaks, CA: SAGE Publications.

Kitzmiller, R. R., Anderson, R. A., \& McDaniel, R. R. Jr. (2010). Making sense of health information technology implementation: A qualitative study protocol. Implementation Science, 5(1), doi:10.1186/1748-5908-5-95.

Lalonde, P-L., Bourgault, M. \& Findeli, A. (2010). Building pragmatist theories of PM practice: Theorizing the act of project management. Project Management Journal, 41(5), 21-36.

Lindgren, M., Packendorff, J., \& Sergi, V. (2014). Thrilled by the discourse, suffering through the experience: Emotions in project-based work. Human Relations, 67(11), 1383-1412.

Lindgren, M., \& Packendorff, J. (2006). Projects and prisons. In D. Hodgson \& S. Cicmil (Eds.), Making Projects Critical (pp. 111-131). London, United Kingdom: Palgrave Macmillan. 
Lindner, F., \& Wald, A. (2011). Success factors of knowledge management in temporary organizations. International Journal of Project Management, 29(7): 877-888.

Lindseth, A., \& Norberg, A. (2004). A phenomenological hermeneutical method for researching lived experience. Scandinavian Journal of Caring Science, 18(2): 145-153.

Lundin, R. A., Arvidson, N., Brady, T., Ekstedt, E., Midler, C., \& Sydow, J. (2015). Managing and working in project society: Institutional Challenges of Temporary Organizations. Cambridge: Cambridge University Press.

Lunkka, N., \& Suhonen, M. (2015). Ambiguous meanings of projects as facilitators of sensegiving, Journal of Nursing Management, 23(7), pp. 842-850.

Löfgren, K., \& Poulsen, B. (2013). Project management in the Danish central government, Scandinavian Journal of Public Administration, 17(2): 61-78.

Maitlis, S. (2005). The social processes of organizational sensemaking. Academy of Management Journal, 47(1): 21-49.

Maitlis, S., Vogus, T., \& Lawrence, T. (2013). Sensemaking and emotion in organizations. Organizational Psychology Review, 3(3), 222-247.

Maitlis, S., \& Christianson, M. K. (2014). Sensemaking in organizations: Taking stock and moving forward. The Academy of Management Annals, 8(1), 57-125.

Midler, C. (1995). "Projectification" of the Firm: The Renault Case. Scandinavian Journal of Management, 11(4), $363-$ 375.

Ministry of Social Affairs and Health, Finland (2010). Health Care Act, No. 1326/2010. Retrieved from: www.finlex.fi/en.

Parker, I. (1999). Introduction: Varieties of discourse and analysis. In I. Parker \& Bolton Discourse Network (Eds.), Critical Textwork: An Introduction to Varieties of Discourse and Analysis (pp-1-12), Buckingham, United Kingdom: Open University Press.

Pietiläinen, V., \& Salmi, I. (2017). An integrative discourse perspective on positive leadership in public health services. Leadership in Health Services, 30(1), 44-58.

Potter, J., \& Wetherell, M. (1987). Discourse and Social Psychology. Thousand Oaks, CA: Sage Publications.

Potter, J. (1996). Discourse analysis and constructionist approaches: theoretical background. In

J. Richardson (Ed.), Handbook of Qualitative Research Methods for Psychology and the Social Sciences (pp. 125-140). Leicester, United Kingdom: British Psychological Society.

Potter, J., \& Hepburn, A. (2007). Discursive psychology: Mind and reality in practice. In A. Weatherall, B. Watson \& C. Gallois (Eds.), Language and social psychology handbook (pp. 160-181), London, United Kingdom: Palgrave Macmillan.

Pohjola, T., Suhonen, M., Mattila, K., \& Meretoja, R. (2016). The work done in healthcare projects. Journal of Nursing, $3(1)$ :.

Sampaio, S., Marinho, M., \& Moura, H. (2014). Systematic review on project actuality. International Journal of Computer Science \& Information Technology, 6(5), 51-63.

Sandberg, J., \& Tsoukas, H. (2015). Making sense of the sensemaking perspective: Its constituents, limitations, and opportunities for further development. Journal of Organizational Behaviour, 36(1), 6-32.

San Martin-Rodriguez, L., Beaulieu, M.-D., Dámour, D., \& Ferrada-Videla, M. (2005). The determinants of successful collaboration: a review of theoretical and empirical studies. Journal of Interprofessional Care, 19(sup1), 132147. 
Sbareca, K., \& Martins, R. (2003). The “Temporary knowledge organization”: an enrichment of the traditional organizational project management paradigm. In R. Madanmohan (Ed.), Leading with Knowledge. Knowledge Management Practices in Global Infotech Companies. New Delhi, India: Tata Magraw-Hill.

Schutz, A. (1967). The Phenomenology of the Social World. Evanston, IL: Northwestern University Press.

Sjöblom, S., Löfgren, K., \& Godenhjelm, S. (2013). Projectified politics - Temporary organizations in public context. Scandinavian Journal of Public Administration, 17(2), 3-12.

Suhonen, M., \& Paasivaara, L. (2015). Project work in Finnish KASTE-projects. Scandinavian Journal of Public Administration, 19(1), 3-19.

Thurlow, A., \& Helms Mills, J. (2009). Change, talk and sensemaking. Journal of Organizational Change Management, 22(5), 459-479.

van de Ven, A. H., \& Poole, M. S. (2005). Alternative approaches for studying organizational change. Organization Studies, 26(9): 1377-1404.

van der Hoorn, B. (2015). Playing projects: Identifying the flow in the "lived experience". International Project Management Journal, 33(5), 1008-1021.

Weick, K. (1979). The Social Psychology of Organizing (2nd edn). Reading, MA: Addison-Wesley.

Weick, K. E. (1995). Making Sense of Organization. Thousand Oaks, CA: SAGE Publications.

Weick, K. E., \& Quinn, R. E. (1999). Organizational change and development. Annual Reviews Psychology, 50(1), 361386.

Weick, K. E., Sutcliffe, K. M., \& Obstfeld, D. (2005). Organizing and the process of sensemaking. Organization Science, 16(4), 409-421.

Wetherell, M. (2007). A step too far: Discursive psychology, linguistic ethnography and questions of identity. Journal of Sociolinguistics, 11(5), 661-681.

Whittle, A. (2006). The paradoxical repertoires of management consultancy. Journal of Organizational Change Management, 19(4), 424-443.

Winch, G., Meunier, M-C., Head, J., \& Russ, K. (2012). Projects as the content and process of change: The case of the health and safety laboratory. International Journal of Project Management, 30(2): 141-152.

\section{Biographies}

Nina Lunkka, PhD (Health Admin.) currently works as a post-doctoral researcher at Oulu Business School at University of Oulu, Finland. In her dissertation, Lunkka focused on hospital change project actuality. In her present research work, she focuses on transformative organizing practices in healthcare setting.

Ville Pietiläinen, D.Sc. (Admin.) serves as a senior lecturer in leadership psychology at University of Lapland, Finland. In his research work, Pietiläinen approaches professional organisations as dynamic and complex systems. His research questions revolve around supportive leadership role, co-creative space, and interaction dynamics.

Marjo Suhonen, Docent, $\mathrm{PhD}$ (Health Admin.) serves as a university lecturer at University of Oulu, Finland. Her research interests are in healthcare leadership and health management. She has over ten years' experience in teaching health administration and health management science. 